\title{
Alternaria Blight of Tomato: A Review of Disease and Pathogen Management Approaches
}

\section{Surbhi Garg1*, Data Ram Kumar², Suresh Yadav ${ }^{3}$, Mohit Kumar ${ }^{4}$ and Jagdish Yadav ${ }^{5}$}

${ }^{1}$ Department of Plant Pathology, RCA, MPUAT, Udaipur, India

${ }^{2}$ Department of Plant Pathology, SKRAU, Bikaner, India

${ }^{3}$ Division of Genetics, ICAR- IARI, New Delhi, India

${ }^{4}$ Department of Plant Pathology, Dr. Rajendra Prasad Central Agricultural

University, Pusa, Bihar, India

${ }^{5}$ Ph.D Scholar, Division of Plant Pathology, ICAR, IARI, New Delhi, India

*Corresponding Author: Surbhi Garg, Department of Plant Pathology, RCA,

MPUAT, Udaipur, India.
Received: September 14, 2020

Published: October 07, 2020

(C) All rights are reserved by Surbhi Garg., et al.

\begin{abstract}
Taxonomically, genus Alternaria comes under Deuteromycetes phylum which includes different saprophytic and endophytic species. It is famous due to its notoriously destructive pathogens. It majorly affects various plant families e.g. Cucurbitaceae, Cruciferaceae and Solanaceae which are agriculturally important crops possess high nutritional and economical values. The crops suffer from various bacterial, viral, fungal and nematode diseases. Among the above mentioned diseases, early leaf spot disease caused by pathogen Alternaria solani is one of the most devastating diseases resulting in loss upto 78\%. Most of the species of Alternaria lacking in teleomorphic stage whereas few species have teleomorphs in their disease cycle. Alternaria being necrotrophic it leads to severe damage to plant and its produce. Besides the involvement of toxins in pathogenesis or invasion, few genes or gene products also have major effect on pathogenicity. In the present review, we described in detail about efficiency of plant and herbal extract, bio control agents, cow by products and fungicides against $A$. solani, that not only effective in managing the disease but also economic and ecofriendly.
\end{abstract}

Keywords: Alternaria; Crop Pathology; Disease Management; Biological Control Agents

\section{Introduction}

In India, tomato is the one of most important and protected vegetable crop after potato in terms of cultivated area and production which belongs to family Solanaceae. Tomato is famous for its high nutritive value further its fruits can be used either as fresh or in processed forms like paste, ketchup, powder, sauce, soup. Being highly digestible, it promotes secretion of gastric glands and helps in purifying blood. It is rich source of vitamin A, B and C and minerals [23]. Its cultivation has become very popular because of its versatile and rapid growth habits and wider climatic adaptability. Tomato is characterized by presence of trichomes that are glandu- lar hairs which emits aroma when it is cut into parts. It is typically prostrate in nature and has either determinate or indeterminate growth habit based on whether the apical stem terminates into flower or grows profusely into various lateral branches and majority of the shoots form in the axils of leaves. It is deep rooted crop that may extend to thirty centimeters and has extensive secondary root system.

In India tomato is one of the protective cultivated vegetable. In India, tomato crop is grown over an area of 8.14 lakh ha and with the total produce that accounts to nearly 20.51 MT with the productivity of $25.20 \mathrm{~kg} \mathrm{ha}^{-1}$ [4]. Bihar, Karnataka, Uttar Pradesh, 
Orissa and Andhra Pradesh are major states for growing tomato in India under protective and traditional cultivation. The production of tomato in Rajasthan accounts around 9.02 MT with the productivity of $4.44 \mathrm{~kg} \mathrm{ha}^{-1}$ over an area of 2.03 lakh ha [3]. Various fungal diseases such as (Anthracnose, Early blight, Fusarium wilt, Powdery mildew, Buckeye fruit and root rot, Pythium damping-off and fruit rot, damping-off and fruit rot etc.), bacterial diseases such as (Bacterial canker, Bacterial speck, Ralstonia wilt and Bacterial stem rot), viral diseases which includes (Tomato leaf curl virus, mosaic of tomato and Tomato spotted wilt) and Root-knot, Sting and Stubby-root are nematodes diseases that affect tomato production and decrease its economic value or price as it deteriorates its quality.

Among all discussed diseases, early leaf blight of tomato caused by $A$. solani is one of the most devastating disease which majorly occurs in the tropics as well as in subtropics. This disease is air or wind borne and soil borne (crop residues) which is responsible for occurrence and dissemination of this disease [11]. The early blight was most devastating disease as it leads to loss both at pre as well as post-harvest stage that leads to deduction of 35 to $78 \%$ in yield [21].

\section{Distribution and losses}

Early blight of tomato was firstly reported in 1882 in New Jersey, USA [7]. Jones and Grout (1897) published initial work on this disease while working at Vermont. Rands RD [40] was the first to prove that the same pathogen i.e. Alternaria solani incited the leaf and stem diseases on both tomato and potato. In India, this disease was first noticed by Butler in Faizabad, U.P in 1905 [11] reported the losses due to this disease from different part of India to the extent of 48 - 80 per cent. Neergaard P [34] measured yield losses up to $5-50 \%$. There is often confusion between foliar damage and yield loss that is due to its rapid spread and dissemination at the end of the season, when crop is at its harvest stage [42]. Yield can be managed by controlling at initial stage [16]. When host become infected, the quantity and quality of final produce is deteriorated and the infection of secondary pathogens accelerates). Photosynthesis rates and respiration rates increase and decrease respectively in apparently healthy plants [42]. Mamgain A., et al. [29] reviewed that Deuteromycetes phylum, fungal Alternaria consists of different saprophytic and parasitic species and known for its notorious plant pathogen. He found that it has drastic effects on the plant families like Cucurbitaceae, Cruciferaceae and Solanaceae having high dietary and economical food value.

\section{Pathogen}

Taxonomically, Alternaria comes under Phylum: Ascomycota, Subdivision: Pezizomycotina, Class: Dothediomycetes, Order: Pleosporales and Family: Pleosporaceae. Its spores are multicellular and dark pigmented producing long chains or branched ones. They are broader near the bottom and taper to form an elongated beak (muriform). The hypha of fungus is haploid and septate. Morphologically it is branched, light brown in colour at initial growth stage while fully grown mycelium is dark black in colour. The conidiophores are nearly 50 - $90 \mu \mathrm{m}$ in length and are dark black in colour. Conidia are beak shaped, muriform, dark colour, measure size nearly (120 - 296 x $12-20 \mu \mathrm{m})$ and borne singly [7]. A. solani has the ability to sporulate, known as its asexual (imperfect) or anamorphs, however its sexual stage or teleomorphic stage is not found yet. Chlamydospores that are thick walled also have been reported, but they are formed in adverse conditions. They survive as saprophytes and as weak pathogen. The genus is characterized by the formation of polymorphic conidia either single or long branched chains and having cross, horizontal and oblique septa as well as long or short beaks. They are cosmopolitan in nature. This genus is characterized by ascospores, produced in bitunicate asci [56]. Causal organism of early blight of potato and tomato, A. solani was grown well at optimum $\mathrm{pH}$ levels of 6 - 7 with temperature ranging from $25-30^{\circ} \mathrm{C}$ in vitro reported by Alhussaen KM [1].

\section{Host range}

A wide range of species for the genus Alternaria were recorded infecting several crops causing economic loss. Due to evolution this pathogen has wide range of host and infects number of plant of diverse origin. Early blight of potato, leaf spot disease in Withania somnifera is caused by Alternaria alternata [37] and can infect many other plants. Besides plant, it also causes asthma, respiratory infection in AIDS patients and has been responsible from chronic rhinosinusitis. Stem canker of tomato, leaf lesions on Asian pear, lesions on Blumea aurita caused by Alternaria arborescens, Alternaria arbusti, Alternaria blumeae respectively. A. brassicae infect many vegetable crops, Alternaria brassicicola invade on cole crops). Similarly, cumin blight, leaf blight on carrot are caused by $A$. brunsii, $A$. carotiincultae, respectively. A. carthami, A. cinerariae, A. citri, A. conjuncta all found to infect parsnip. A. dauci grows on carrot, crucifers are also infected by other species such as A. dianthi, A. dianthicola, A. euphorbiicola. This wide range of host of Alternaria has attracted the attention of pathologist towards it and various studies are still going on its variability and characterization. 


\section{Symptoms caused by pathogen}

Symptoms of early blight are seen at all stages of plant growth. The symptom appears on every part of plant resulting in defoliation, drying off of twigs and premature fruit drop under favourable conditions [32]. Locke SB [27] reported that symptoms appear first on leaves as brown to dark leathery necrotic spots. Zafar $\mathrm{H}$., et al. [58] reported angular shaped spots of 0.3 to $0.4 \mathrm{~cm}$ in diameter with usually narrow chlorotic, yellow halo zone around the spot. Concentric rings of raised and depressed brown tissue are formed as the spot matures. Thomma BPHJ [55] established that plant tissues suffering abiotic stress, senescence etc. were more susceptible to infection than healthy tissues. Alternaria is a necrotrophic pathogen means kills plant cells first in order to feed on the cell constituents, instead of developing haustoria and penetration peg to derive nutrients and to cause infection as biotrophic pathogens do. Conidia survive on the soil surface and on old dry lower leaves of the plant stated by Jambhulkar PP., et al. [18] and spread when favourable climatic condition prevails. For conidial dispersion, they found the positive correlation with high temperature and negative correlation with low humidity.

\section{Disease cycle}

\section{Overwintering and survival}

As $A$. solani has many stages in the life cycle during pathogenesis hence it has polycyclic life cycle. Overwintering inoculum such as plant debris, infected plant act as a source of primary infection on new plantings of host plant. Asexual spores such as chlamydospores have been reported as a source of inoculum for early blight disease, allowing the pathogen to face cold temperature in or on the soil or micro flora [6]. In uncultivated soil the inoculum remains infective for 5 - 8 months in debris. Dark pigmentation of the hyphae provides resistance to lysis [28]. Mostly infected debris and seed act as substrate for survival of spores. Primarily edaphic, meteorological and biotic factors determine presence in debris and seed as a source. It mainly survives in dry and uncultivated fields [42].

\section{Dissemination and dispersal}

Conidia produced in the spring act as primary inoculum, which are dispersed by splash- or wind- to the lower leaves where they germinate and cause infection [42]. Rain, wind and insects are the principal source of secondary spread of $A$. solani. For example, (Leptinotarsa decemlineata), the Colorado potato beetle act as source of spread the fungus when it feeds on foliage of infected plants [39]. Using spore traps, rapid spore dispersal occurs most in the driest and hottest hour of the day. Till infection doesn't reach the stage at which whole leaves dry up and plants begin to die, a rapid rate of dispersal does not occur. There is similarity between the curve of wind velocity and that of spore dispersal. However, there seems to be no significant correlation between spore dissemination and other weather parameters for effective dispersal of spores they should be in abundant quantity during day time. Positive correlation is found between spore dispersal and disease intensity that's why the quantity of spores increases proportionally to disease intensity.

\section{Infection}

Free moisture is prerequisite for spore germination but it may be stimulated by humidity when reaches to saturation point. Several reports showing the spore germination give different values for minimum, optimum and maximum temperatures for spore germination. Spores could germinate after having a two-hour wetting period at $20^{\circ} \mathrm{C}$ reported by Bashi E and Rotem J [5]. Growth of the germ-tube requires a long wetting period than that of spore germination. Germ-tubes grow to form appressoria and invade the epidermis directly or indirectly through wounds or stomata. Favourable inoculum dose and wetting hours, the minimum temperature $<10^{\circ} \mathrm{C}$, the maximum $>35^{\circ} \mathrm{C}$ and the optimum range between $20^{\circ} \mathrm{C}$ and $30^{\circ} \mathrm{C}$ is necessary for infection showed by Rotem J [42]. Depending on age and susceptibility of plants incubation periods vary from infection to symptom development greatly [42]. Increased wounding of the epidermis can increase in severity after sandstorms. The primary symptoms appear as necrotic with chlorotic, yellow halos. Mycelia from necrotic lesions that produce conidia that invade healthy leaves begin to produce secondary infections. As the conidia are unable to infect directly or by formation of appressoria it invades through wounds and stomata and infect tuber and periderm [14]. Infection reduces significantly by wound healing, by suberisation and by formation of abscission layer.

\section{Epidemics}

Studies have revealed that free water is crucial for disease occurrence [39] and leaf wetness period is responsible for disease severity and development and its variation in disease progression rate. Increased leaf age, crowded plants, heavy fruit load and weather parameters above recommended rainfall or dew and sun shade also enhance symptoms of disease. Pathogen response varies with epidemiological conditions, depending on the situation of weather

Citation: Surbhi Garg., et al. "Alternaria Blight of Tomato: A Review of Disease and Pathogen Management Approaches". Acta Scientific Agriculture 4.11 (2020): 08-15. 
[42]. Weather parameters indirectly influence the resistance of the host, in certain cases [42]. Cooler temperatures may decrease the growth of the plant for instance, while short photoperiod are responsible for decreasing sugar content in leaves thus increasing susceptibility of the plant. However, disease progression curves vary depending on site and prevailing climatic conditions. Hence, disease dissemination and perpetuation greatly depends on temperature, moisture, wetting hours and spread at a very rapid rate. So, it is necessary to discover and follow an integrated approach to manage this disease at initial level.

\section{Disease management}

Since, Alternaria species have wide host range and multiply at a very rapid rate resulting in large economic losses, therefore there is a stringent need to effectively management of pathogen and to adopt integrated disease management practices to minimize its losses. So, this review focuses on the different methods or strategies which are therefore needed for management of Alternaria.

\section{By selecting resistant varieties}

It is the foremost practice to manage any disease. The cultivation of susceptible varieties should be avoided and field sanitization should be adopt in order to remove infected residues that act as a source of overwintering inoculum that survive from a previous persists on the soil and plant surface. Use of resistant varieties is stable and convenient method for controlling disease. It is one of the economical means to farmers as it reduces cost of cultivation for managing the disease. This is now attracting great interest of breeders to find stable source of resistance against Alternaria. Breeders across the entire world are working on the expression of various resistance genes encoding for proteins essential for inducing resistance.

Genotype diversity against Alternaria for different host range

\begin{tabular}{|l|c|c|}
\hline Host & Genotype available & References \\
\hline Cucumber & MR-1(Resistant) & {$[54]$} \\
\hline Watermelon & $\begin{array}{c}\text { Sel-1 and Sugar baby (Resistant), } \\
\text { Durgapura Meetha, WHY and } \\
\text { WHY-4, AY, (Highly susceptible), } \\
\text { Milan, R-187-2, RW-177-3 and } \\
\text { RW-1 (moderately susceptible) }\end{array}$ & [31] \\
\hline Bottle gourd & $\begin{array}{r}\text { Azad Harit, 7003 and 7002(High- } \\
\text { ly resistant) }\end{array}$ & {$[22]$} \\
\hline Chilli & $\begin{array}{r}\text { CA 87-4 and CA 748(Highly } \\
\text { resistant) }\end{array}$ & {$[53]$} \\
\hline \multirow{7}{*}{ Tomato } & $\begin{array}{r}\text { Arka Abha, Arka meghali, IIHR- } \\
\text { 305, Arka Alok, Arka Saurabh, } \\
\text { IIHR-308, IIHR-2285, IIHR-2266 } \\
\text { and IIHR-2288 were (highly } \\
\text { resistant) }\end{array}$ & \\
\hline
\end{tabular}

\section{By ground preparation}

The previous crop residues should be discarded. Formation of raised beds should be practiced rather than flat beds. Balanced dose of fertilizers especially potassium, FYM should be applied and the dose of other nutrients should be applied as prescribed in package of practices.

\section{By seed treatment}

The other effective method is controlling Alternaria diseases is seed treatment as it aids in minimizing primary infection. Walker JC [57] suggested the hot water treatment to control Alternaria in crucifers at $50^{\circ} \mathrm{C}$ temperature for 30 minutes and Ellis MB [13] suggested the same for time period of 25 minutes to control its infection from Crucifers. Combination of Thiram+ Captan (1:1) @ 0.3\% and Zineb @ (0.25\%) can be applied as seed treatment with four sprays were found effective in managing disease in chilli stated by Jharia HK., et al [20].

\section{By bio-control agents}

Keeping in mind the inhibitory properties of various fungi, bacteria and actinomycetes, various bio-control agents is being recommended to control disease. It means controlling the disease by the use of living organism that is inhibitory to another microorganism. They are the need of hour and getting economic and commercial importance over conventional means of management such as use of fungicides, insecticides. Firstly, they are cheaper and don't have residual effect, secondly they are ecofriendly and have long lasting effect, thirdly they are effective as compare to conventional means. Last but not least they also nourish the soil by providing nutrients, increasing biomass in soil, hence, improve structural, physical, chemical properties of soil. They have different mode of action in managing pathogen but main gist of their action is competition.

\begin{tabular}{|l|c|}
\hline Bio-control agents & References \\
\hline Bacillus subtilis and Trichoderma viridae & {$[29]$} \\
\hline $\begin{array}{l}\text { Trichoderma viride, T. koningii, T. harzianum, T. } \\
\text { hamatum, Pseudomonas fluorescens }\end{array}$ & {$[10]$} \\
\hline $\begin{array}{l}\text { T. harzianum, T. viride, P. fluorescens and B. } \\
\text { subtilis }\end{array}$ & {$[58]$} \\
\hline T. harzianum and T. viride & {$[24]$} \\
\hline $\begin{array}{l}\text { T. viride, T. koningii, T. virens, T. harzianum, and T. } \\
\text { pseudoganglia, B. subtilis, P. fluorescens }\end{array}$ & \\
\hline
\end{tabular}

\section{By plant extracts and natural products}

Usage of different plant extracts and herbal products are being increased because they have no detrimental effect on human health and ecofriendly. The extracts of Prosopis spicigera, Ipomoea palmate, Argemone Mexicana, Cenchrus catharticus, Mentha piperita, Allium cepa, A. sativum, Lawsonia inermis, Datura stramonium and 
Clerodendrum inerme found to have inhibitory effect on conidia germination of $A$. brassicae extracted from cauliflower plant [46]. Six medicinal plants (Datura, Neem, Calotropis, Eucalyptus, Parthenium and Polyalthia) were evaluated for inhibitory effect against $A$. brassicae causing blight in mustard. Among all, Calotropis, Eucalyptus and Polyalthia extracts, had shown significant effect in reducing the growth of the pathogen [38]. Ching HW., et al. [8] reported that ethanol extract of Polygonum perfoliatum had high inhibitory action against sporulation of $A$. brassicicola. The neem extract was tested at $0.1 \%$ and $0.01 \%$, against $A$. solani, showed high efficacy to inhibit the radial growth (43.3 and $26.7 \%$ respectively) [44]. The percent inhibition of Alternaria by plant extracts varied from 44.59 to $8.25 \%$. Lantana and Datura found significantly effective as they restricted growth up to 44.59 and $30.88 \%$ respectively while Tamarind found least effective as it reduced the growth up to $8.25 \%$ only [10]. Inhibition effect of Azadirachta indica was tested for $A$. solani and Fusarium oxysporum, the causing early blight and wilts of tomato respectively, their inhibitory effect studied at various concentrations (5, 10 and 20\%). Neem extract inhibited mycelial growth of both fungi (A. solani and Fusarium oxysporum) and the degree of suppression proportionally increased with increasing concentration of extracts. Maximum percent inhibition was of $20 \%$ aqueous Neem leaf extract that decreased the incidence of early blight from 53.2 to $42.5 \%$ after period of 2 weeks and 100 to $79.2 \%$ after period of 4 weeks stated by Hassanein NM., et al [17]. Efficiency of plant extracts was evaluated against dry rot of Aloe Vera caused by A. alternata at 5 and $10 \%$ concentration. Among all Neem leaf extract and Oscimum sanctum were found effective and inhibit radial growth (58.6\%, 54.7\% respectively) [2]. At 4\% concentration the inhibition percent of seven plants extract Crotalaria (36.6\%), Citrus (27.3\%), Neem (23.7\%), Polyalthia (23.3\%), Datura (21.3\%), Oxalis (20.09\%) and Muntingia (20.09\%) was evaluated. Six extracts @ 2\% concentration showed percent growth inhibition significantly namely, Crotalaria (16.6\%), Neem (10\%), Capsicum (7.1\%), Datura (6.6\%), Polyalthia (6.3\%) and Citrus (5.5\%) against $A$. solani [41]. Hence, large number of plant extracts are available that have promising results against Alternaria meanwhile they don't have health hazards and are also economic and feasible in use.

\section{Through cow by-products}

The prophylactic and preventive effects of cow by products can also be utilized to combat the detrimental effect of $A$. solani. Antagonistic property of cow dung and cow urine, in a ratio of 3:1 was determined [35] and it plays an important role in managing pathogens. Noor A [36] reported the antagonistic effect of cow urine and confirmed that it can be used good and potential pesticide. It used singly or in combination with some botanicals mixed in various concentrations against pests and diseases having significant results. Cow milk has also been found promising effective against whitefly vector of chilli leaf curl virus. The efficacy of cow by products was evaluated in composted form (vermi compost) and noncomposted form both respectively with different concentrations such as $(0.5 \%, 2 \%, 3.5 \%$ and $5 \%)$ for observing radial growth and sporulation behavior of different fungal species. Among them, radial growth (29.75 mm, $63.50 \mathrm{~mm}, 25.25 \mathrm{~mm})$ and $32.50 \mathrm{~mm}$ of various fungal species A. alternata, Fusarium oxysporum, Colletotrichum capsici and Curvularia lunata was found respectively. Both posed inhibitory effect against mycelial growth however, degree of suppression proportionally increased with the increase in concentration [45]. Deshmukh SS., et al. [12] confirmed the inhibitory property of these extract at various concentration viz; 5\%, 10\%, 15\% and 20\% against Penicillium notatum, F. oxysporum, Aspergillus, A. solani. Among that $A$. solani was inhibited most and its growth was $1.9 \mathrm{~cm}$, $1.8 \mathrm{~cm}$ and no growth at $10 \%, 15 \%$, and $20 \%$ respectively whereas in control it had growth of $2 \mathrm{~cm}$. Same was also confirmed by Jandaik S., et al. [19] and determined antifungal activity of cow urine at various concentrations viz., 5, 10 and 15\% against (F. oxysporum, $R$. solani, and S. rolfsii) that were purified from infected plants of both Fenugreek, Okra. Among all, cow urine @ 15\% was found most effective. When their inhibitory effects were evaluated, highest inhibition was examined against F. oxysporum (78.57\%) @15\% of cow urine followed by $R$. solani $(78.37 \%)$ and S. rolfsii $(73.84 \%)$. The antagonistic effect of panchagavya (mixture of cow dung, cow urine, buttermilk, cow ghee and water) was evaluated against various pathogens: Candida albicans, Aspergillus niger, A. flavus, A. solani. In case of $A$. solani the diameter of inhibition zone was $20 \mathrm{~mm}, 21.5$ mm and 37.5 mm @ 500,1000 mg/ml concentration respectively. Inhibition effect is because of antiseptic and prophylactic properties of cow dung. Lactoferrin B and lactic acid bacteria present in milk and butter milk respectively are major anti-microbial proteins. Lactic acid bacteria (LAB) also produces anti-bacterial and anti-fungal metabolites such as phenyl lactic acid, cyclic dipeptides, 3-hydroxylated fatty acid and several proteinaceous compound these all exhibit antimicrobial property [15]. Hence, it can be stated that cow by products can also be used to manage various diseases in the list of organic and ecofriendly means. 


\section{By fungicides}

Above methods are effective to manage the disease but these have their own limitations because their effects are slow and take long time for their potential results. So, as per the severity and immediate results one we has to go for chemical treatment. Sahni ML and Singh RP [43] proved Thiram (75\%) as the most effective @ 5000 ppm and its maximum inhibition was reported with Thiram (TMTD 80\%) and Arasan 50\% @10,000 ppm. Sinha PP and Prasad RK [51] claimed fungicide Captafol to be best against Alternaria blight of cauliflower. Inhibition effect of Mancozeb was found most promising against radial growth of pathogen @0.2\% [9]. Not only fungicides but different hormones such as Indole-3-Butyric Acid (IBA) or Naphthalic acid (NA) @ $200 \mu \mathrm{g} /$ lit concentrations for 30 minutes have been proved to manage the fruit rot caused by $A$. alternata as they induce resistance in plant [33]. For better results combination of fungicides with compatibility can be used. Same was proved by Singh M., et al. [49] that combined product of Emisan-6 with Indofil M-45 was found best against Alternaria blight of potato, followed by the combined product of Emisan-6 with Indofil Z-78. Singh NK., et al. [50] also confirmed the effectiveness of Mancozeb against Alternaria. Alternaria leaf blight of bottle gourd was managed by spraying @ Indofil M45@ 0.2\% followed by Chlorothalonil, Ridomil, Copper oxychloride, Jkstein, Indofil Z-78 and Topsin-M. Katiyar A., et al. [22] reported that three sprays of Dithane M-45 @0.25\% proved better than other fungicides such as Kavach, Baycor Foltaf, Bayleton and Contaf 5 EC was suggested by Singh A and Singh D [47]. They suggested three spray of Dithane M-45 (0.25\%), Foltof $(0.25 \%)$ or Kavach $(0.1 \%)$ at 10 days' interval to control A. brassicicola. Singh K and Rai M [48] stated that application of Indofil M-45, Vitavax, Indofil Z-78, and Kavach was effective in reducing the fungal growth of $A$. alternata followed by Bavistin, Thiram and Benlate fungicide in vitro. The efficiency of Carbendazim, Copper oxychloride and Mancozeb @ $0.2 \%$ was evaluated against early blight of tomato cv. Kohinoor-1 at Allahabad, Uttar Pradesh that decreased the disease incidence, enhanced plant height and yield over the control. Carbendazim resulted in the lowest disease intensity and highest yield (6.1 Kg per plot), followed by Mancozeb and copper oxychloride [52]. The most effective fungicide was Difenoconazole (Score) which inhibit the mycelial growth up to $78.61 \%$ which was followed by Carbendazim (76.67\%t) whereas minimum inhibition (50.74\%) of the mycelial growth was recorded in Chlorothalonil (Kavach) [26]. Combined effect of systemic and contact fungicides in managing blight of potato incited by fungus $A$. solani was determined in vitro different fungicides indicated that Fenamidone 10\% + Manco- zeb 50\% (Sectin) gave the inhibition (83.79\%) of radial growth of pathogen followed by Propiconazole 25\% EC (83.62\%), Dimethomorph 9\% + Mancozeb 60\% (79.07\%), Cymoxanil 8\% + Mancozeb 64\% (79.03\%) and Mancozeb (56.85\%) were also inhibited radial growth of the pathogen. In vivo studies evaluating different fungicides indicated that Fenamidone 10\% + Mancozeb 50\% (0.2\%) was most effective followed by Propiconazole 25\% EC, Dimethomorph 9\% + Mancozeb 60\%, Cymoxanil 8\% + Mancozeb 64\% (0.2\%) and Mancozeb $(0.25 \%)$ and also economical in reducing the disease severity of the early leaf blight and enhancing yield over control [25].

\section{Conclusion}

It can be summarized that Alternaria is a notorious pathogen, having wide range of host and cause significant economic losses that is major concern of pathologist to evolve an effective and integrated approach to combat its harmful effects. It growth and multiplication is affected by various climatic and edaphic factors that enhance its inoculum potential that leads to severe epidemic. Therefore, it is required to develop integrated disease management practices IDM approach because only use of chemicals is not sufficient and realistic to manage it. As these have residual and harmful effects on human health. Therefore, by the use of stable resistance source, application of bio agents, plant and herbal extract, cow by products and alteration of agronomic practices like balanced nutrition, field sanitization, crop rotation and using trap crops etc. can help out to find the solution from this disease. They are not only economical but also feasible, ecofriendly and safe.

\section{Bibliography}

1. Alhussaen KM. "Morphological and physiological characterization of Alternaria solani isolated from tomato in Jordan Valley". Research Journal of Biological Sciences 7 (2012): 316-319.

2. Anamika Sobita S. "Inhibitory effect of botanical extracts against Alternaria alternata of aloe vera dry rot". Archives of Phytopathology and Plant Protection 15 (2014): 1462-1466.

3. Anonymous. "Report on state domestic product of Rajasthan state". Directorate of Horticulture Board. Government of Rajasthan (2017).

4. Anonymous. "The $1^{\text {st }}$ Advance estimates of production of major crops of India”. Department of Agriculture, Cooperation and Farmers Welfare. Government of India (2019).

5. Bashi E and Rotem J. "Adaptation of four pathogens to semi-arid habitats as conditioned by penetration rate and germinating spore survival". Phytopathology 64 (1974): 1035-1039. 
6. Basu P K. "Existence of chlamydospores of Alternaria porri f. sp. solani as overwintering propagules in soil". Phytopathology 61 (1971): 1347-1350.

7. Bose TK and Som MG. "Vegetable Crops in India". Nayaprakash Publishing, Calcutta (1986): 773.

8. Ching HW., et al. "Effect of oriental medicinal plant extracts on spore germination of Alternaria brassicicola and nature of inhibitory substances from speed weed". Plant Disease 91.12 (2007): 1621-1624.

9. Choulwar AB., et al. "Efficacy of fungitoxicants on the mycelial growth of A. solani”. Pestology 13 (1989): 17-19.

10. Dalpati NNS., et al. "Efficacy of some bioagents and botanicals against Alternaria macrospora causing leaf spot of cotton". Journal of Plant Disease Sciences 5.1 (2010): 95.

11. Datar VV and Mayee CD. "Assessment of loss in tomato yield due to early Blight". Indian Phytopathology 34 (1981): 191195.

12. Deshmukh SS., et al. "Antifungal activity of cow urine". Journal of Pharmacy and Pharmacology 2.5 (2012): 27-30.

13. Ellis MB. "Alternaria brassicae". In: Descriptions of pathogenic fungi and bacteria (No. 162), Commonwealth Mycological Institute (CMI), Kew, Surrey, England (1968).

14. Folsom D and Bonde R. "Alternaria solani as a cause of tuber rot in potatoes”. Phytopathology 15 (1925): 282-289.

15. Gajbhiye SP., et al. "Antimicrobial Activities (Antibacterial and Antifungal) effect of Panchagavya alone prepared by fermentation method". World Journal of Pharmacy and Pharmaceutical Sciences 7.7 (2018): 1336-1349.

16. Harrison MD and Venette JR. "Control of potato early blight and its effect on potato yield". American Potato Journal 47 (1970): 81-86.

17. Hassanein NM., et al. "Control of tomato early blight and wilt using aqueous extract of neem leaves”. Phytopathologia Mediterranea. 49 (2010): 143-151.

18. Jambhulkar PP., et al. "Altering conidial dispersal of Alternaria solani by modifying microclimate in tomato crop canopy". Plant Pathology Journal 32.6 (2016): 508-518.

19. Jandaik S., et al. "Efficacy of cow urine as plant growth enhance and antifungal agent". Advances in Agriculture (2015).

20. Jharia HK., et al. "Efficacy of fungicides in the control of fungal diseases of chillies”. Indian Phytopathology 39 (1977): 341-
343.

21. Jones JB., et al. "Compendium of tomato diseases, St. Paul". American Phytopathological Society, St. Paul, Minnesota, USA (1993): 28-29.

22. Katiyar A., et al. "Sources of resistance in bottle gourd to Alternaria leaf spot". Annals of Plant Protection Sciences 9.1 (2001): 155-157.

23. Khoso AW. "Growing vegetable in Sindh". $2^{\text {nd }}$ Edition Allied Printing Corporation, Hyderabad (1991):136.

24. Koley S., et al. "In vitro efficacy of bio control agents and botanicals on the growth inhibition of Alternaria solani causing early leaf blight of tomato". International Journal of Bio-Resource, Environment and Agricultural Sciences 1.3 (2015): 114-118.

25. Kumar A., et al. "Efficacy of Newly Fungicides on Early Blight of Potato under In vivo and In vitro conditions". International Journal of Current Microbiological and Applied Science 7 (2018): 16-22.

26. Kumar V., et al. "Evaluation of different fungicides against Alternaria leaf blight of tomato (Alternaria solani)". International Journal of Current Microbiological and Applied Science 6.5 (2017): 2343-2350.

27. Locke SB. "Resistance to early blight and septoria leaf spot in the genus Lycopersicon". Phytopathology 39 (1949): 829-836.

28. Lockwood JL. "Lysis of mycelium of plant-pathogenic fungi in natural soil”. Phytopathology 50 (1960): 787-789.

29. Mamgain A., et al. "Alternaria pathogenicity and its strategic control”. Research Journal Biology 1 (2013): 01-09.

30. Matharu BK., et al. "Synthesis and antifungal potential of 2-chlorobenzal derivatives". Pesticide Research Journal 18.2 (2006): 113-115.

31. Mathur K and Shekhawat KS. "Fruit rot of watermelon". Indian Journal of Mycology and Plant Pathology 22 (1992): 80.

32. Mathur K and Shekhawat KS. "Chemical control of early blight in Kharif sown tomato". Indian Journal of Mycology and Plant Pathology 16 (1986): 235-238.

33. Mayee CD and Datar VV. "Phytopathometry Technical Bulletin". Marathwad Agril. Uni., Parabhani (1986): 25.

34. Neergaard P. "Danish species of Alternaria and Stemphylium". Taxonomy, parasitism, economic significance. Einar Munksgaard, Copenhagen (1945).

35. Nene YL., et al. "Disease and insect pest management practices in ancient and medieval India". Agricultural Heritage of India 
(Proceeding of National Conference on Agriculture Heritage India) held (2002).

36. Noor A. "Cow urine, butter milk and cow dung in the management of insect pest of chilli and seed spices. National Seminar on Cow in Agriculture and human health". A.R.S., Kota, Asian agri History Foundation (Rajasthan Chapter), India (2003).

37. Pati PK., et al. "Studies on leaf spot disease of Withania somnifera and its impact on secondary metabolites". Indian Journal of Microbiology 48 (2008): 432-437.

38. Patni CS., et al. "Efficacy of botanicals against Alternaria blight (Alternaria brassicae) of mustard". Indian Phytopathology 58.4 (2005): 426-430.

39. Rands RD. "Early blight of potato and related plants". Wisconsin Agricultural Experimental Station Research Bulletin 42 (1917a): 1-48.

40. Rands RD. "Early blight of tomato and related plants". Wisconsin Agricultural Experimental Station Research Bulletin 42 (1917): 1-48.

41. Ravikumar MC and Garampalli RH. "Antifungal activity of plants extract against Alternaria solani, the causal agent of early blight of tomato". Archives of Phytopathology and Plant Protection 46.16 (2013): 1897-1903.

42. Rotem J. "The genus Alternaria: biology, epidemiology and pathogenicity". APS Press, St Paul, Minnesota (1994).

43. Sahni ML and Singh RP. "Bioassay of tetramethylthiuram-disulphide fungicide". Indian Phytopathology 20 (1967): 71-73.

44. Sharma A., et al. "Antifungal effect of neem extract on some common phytopathogenic fungi". Advances in Plant Sciences 20.2 (2007): 357-358.

45. Sharma R., et al. "Impact of cow urine and composted cow dung on the incidence of seed borne phytopathogenic fungi". International Journal of Plant Sciences 5.2 (2010): 579-581.

46. Sheikh RA and Agnihotri JP. "Antifungal properties of some plant extracts". Indian Journal of Mycology and Plant Pathology 2 (1972): 143-146.

47. Singh A and Singh D. "Efficacy of fungicides against Alternaria leaf spot of cabbage”. Crop Research 23.1 (2002): 192-193.

48. Singh K and Rai M. "Evaluation of chemicals against Alternaria leaf spot of brinjal". Annals of Plant Protection Sciences 11.2 (2003): 394-395.
49. Singh M., et al. "Efficacy of different fungicides for control of early blight of potato caused by Alternaria solani". Annals of Plant Protection Sciences 5.1 (1997): 114-115.

50. Singh NK., et al. "Management of Alternaria leaf spot disease of tomato". Indian Phytopathology 54 (2001): 508.

51. Sinha PP and Prasad RK. "Chemical management of Alternaria blight of cauliflower seed crop". Indian Journal of Mycology Plant Pathology 19 (1989): 204-205.

52. Sudarshana VR., et al. "Efficacy of fungicides and botanicals against early blight of tomato". Annals of Plant Protection Sciences 20.1 (2012): 245-246.

53. Sujatha Bai E., et al. "Alternaria fruit rot disease of chilli- a serious malady in Tamilnadu". Indian Phytopathology 46 (1993): 338.

54. Thomas CE., et al. "Inheritance of resistance to Alternaria cucumerina in Cucumis melo line MR-1". Plant Disease 74 (1990): 868-870.

55. Thomma BPHJ. "Alternaria spp. from general saprophyte to specific parasite”. Molecular Plant Pathology 4 (2003): 225236.

56. Verma N and Verma S. "Alternaria diseases of vegetable crops and new approaches for its control". Asian Journal of Experimental Biological Sciences 1.3 (2010): 681-692.

57. Walker JC. "Diseases of crucifers". In: Diseases of vegetable crops, McGraw Hill Book Co., New York, USA (1952): 150-152.

\section{Assets from publication with us}

- Prompt Acknowledgement after receiving the article

- Thorough Double blinded peer review

- Rapid Publication

- Issue of Publication Certificate

- High visibility of your Published work

Website: www.actascientific.com/

Submit Article: www.actascientific.com/submission.php

Email us: editor@actascientific.com

Contact us: +919182824667 